\section{Characterizing the Frequency Distributions for Fruit Firmness of Sweet Cherry Cultivars}

\author{
Kareen Stanich, Margaret Cliff ${ }^{1}$, and Cheryl Hampson \\ Agriculture and Agri-Food Canada, Summerland Research and Development \\ Centre, 4200 Highway 97 South, P.O. Box 5000, Summerland, BC, V0H \\ 1Z0, Canada
}

Additional index words. firmness, frequency distributions, Prunus avium

\begin{abstract}
Fruit firmness is among the most important characteristics for the quality of sweet cherries. However, little has been published on its underlying frequency distribution. This research was undertaken to examine the firmness distributions $(n=48)$ from six cultivars [Sandra Rose, Summit, Lapins, Skeena, Sumtare (Sweetheart ${ }^{\mathrm{TM}}$ ), and $13 \mathrm{S2009}$ $\left(\right.$ Staccato $\left.^{\mathrm{TM}}\right)$ ], two field treatments [with or without gibberellic acid (GA)], two storage times ( 0 and 7 days), and two growing seasons (2013 and 2014). Fruit was sampled $(n=300)$ at optimal maturity and firmness was evaluated using the FirmTech2 Fruit Firmness Tester. Firmness distributions were examined using descriptive statistics: mean, median, standard deviation (SD), minimum, maximum, range, skewness, and excess kurtosis. Nonnormality was assessed using skewness and kurtosis test statistics. Exponential models were fitted to the ascending and descending portions of the distributions and the proportion of "too soft" (percentage $<2.56 \mathrm{~N} \cdot \mathrm{mm}^{-1}$ ) and "too hard" (percentage $>4.71$ $\mathbf{N} \cdot \mathbf{m m}^{-1}$ ) fruit was determined. A relatively high proportion of distributions were nonnormal (16/24 to 18/24), either skewed, peaked, or both. While most skewed distributions were skewed negatively, with a higher proportion of softer fruit, the distributions for 'Sandra Rose' were skewed positively, with a higher proportion of firmer fruit. Principal component analysis (PCA) showed seasonal, cultivar, treatment, and storage effects among three subsets of cultivars with differing characteristic firmness. The softer early-harvest cultivars (Sandra Rose and Summit) had a higher proportion of "too soft" fruit. GA and storage treatments increased mean firmness and reduced the proportion of "too soft" fruit. The firmer late-harvest cultivars (Skeena, Sumtare, and 13S2009) had a small proportion of "too hard" fruit ( $0 \%$ to $19.3 \%)$. The work gained insight into the nature of the firmness distributions for sweet cherries and the type of statistics that are most appropriate for analyzing the data.
\end{abstract}

Determination of fruit size and weight is important in horticulture to estimate yield and the proportion of fruit in each grade (Zhang and Robson, 2002). Typically, the distribution of apple fruit weight fits a normal distribution (Webb et al., 1980); although some exceptions exist (Clarke, 1990; Judd et al., 1989), they appear to be tolerated statistically (Zhang and Robson, 2002).

Although fruit weight distributions are frequently reported in the literature, fruit firmness distributions have not been reported. This is particularly surprising given that

\footnotetext{
Received for publication 13 Nov. 2015. Accepted for publication 5 Apr. 2016.

This work was supported by funding from the Agri-Innovation Program (AIP), as part of the Growing Forward initiative.

We would like to thank Darrell-Lee McKenzie (SuRDC, BC) for assistance with project conception, acquisition of the cherries, and technical support in the laboratory. We also acknowledge the support of SuRDC staff Linda Herbert and Chris Pagliocchini, and thank Pol Tijskens (Wageningen University, NL) for useful discussions.

${ }^{1}$ Corresponding author. E-mail: margaret.cliff@ agr.gc.ca.
}

fruit firmness is such an important quality attribute for both apples (Harker et al., 2008) and cherries (Dever et al., 1996). Means and SDS may be sufficient to characterize firmness if the underlying distributions are normally distributed; however, the shape of the firmness distributions for cherry cultivars is unknown.

For apples, firmness, along with juiciness and crispness, is associated with freshness (Péneau et al., 2007). For cherries, the visual characteristics of the fruit and stem and absence of defects and injuries are key visual indices of freshness (Drake et al., 1989). However, the United States Department of Agriculture (USDA) uses firmness along with other quality factors to establish cherry grades (USDA, 2005).

Firmness and size are also selection criteria in the cherry breeding program at the Summerland Research and Development Center (SuRDC, Summerland, BC, Canada), along with self-fertility, rain-splitting resistance, sweetness, stem quality, and other traits (Hampson, 2014). In general, firmer fruit are preferred by consumers. Recently, Hampson et al. (2014) determined the ideal range for cherry firmness, using Just-About-Right methodology. Cherries with firmness values less than $2.56 \mathrm{~N} \cdot \mathrm{mm}^{-1}$ and greater than $4.71 \mathrm{~N} \cdot \mathrm{mm}^{-1}$ were considered "too soft" and "too hard," respectively by consumers.

Texture measurements are influenced by the product water status, cell wall physical properties, and tissue structure - all of which act together in the characterization of firmness (Landahl et al., 2004). Research has investigated the mechanical properties of fruit cells to gain insight into the strength of tissues, by evaluating tensile properties (De Belie et al., 2000; Harker et al., 1997) and compression characteristics (Lin and Pitt, 1986); however, there is no research available for cherries.

Understanding the agronomic factors that contribute to size and firmness variation is important in agricultural research to establish appropriate cultural practices and understand environmental influences (Searle et al., 2003). Tijskens et al. (2007) have developed a model to relate harvest maturity of nectarines with firmness, using a "biological shift factor" to account for differences due to season, cultural practices, and growing conditions. Such work allows for fruit to be nondestructively graded, so that sorting and handling can proceed according to the firmness category; however, no such model is available for cherries.

Lechaudel et al. (2007) have developed models to show how environmental factors influence the accumulation of water, structural and nonstructural dry matter during fruit development of mangos. These models tracked changes in fruit growth using parameters linked to wall extensibility and yield threshold pressure, as well as evaluated changes in shrinkage/swelling using surface conductance of the fruit skin, the elastic modulus, and the hydraulic conductivity of the fruit; however, no such models are available for cherries.

Therefore this research was undertaken to 1) characterize sweet cherry firmness distributions with descriptive statistics, exponential models, and area-under-the-curve calculations, and 2) use the calculated parameters along with multivariate statistics to gain insight into the effects of cultivar, treatment, storage time, and year.

\section{Materials and Methods}

Cherry trees/cherries. Cherry trees were selected from existing plots associated with the SuRDC Cherry Breeding Program. Trees had been propagated on Mazzard seedling rootstocks and were between 7 and 34 years of age. Six cultivars (Sandra Rose, Summit, Lapins, Skeena, Sumtare, and 13S2009) were selected for the study with a wide range of firmness and harvest dates (Table 1). Each cultivar was sampled from untreated control (C) trees, or trees sprayed with GA. The GA application consisted of $20 \mathrm{mg} \cdot \mathrm{L}^{-1} \mathrm{GA}$ (Fruitsize, Terralink Horticulture Inc., Abbotsford, Canada) plus $50 \mathrm{~mL}$ surfactant (Agral 90, Syngenta, Guelph, Canada), and was applied at the early pit hardening stage of fruit growth.

Although 'Sumtare' and '13S2009' have been trademarked Sweetheart ${ }^{\mathrm{TM}}$ and Staccato ${ }^{\mathrm{TM}}$, 
Table 1. Harvest date, size, and compositional analyses of cherry samples in 2013 and 2014 evaluated for six cultivars, treated with and without gibberellic acid (GA).

\begin{tabular}{|c|c|c|c|c|c|c|c|c|c|}
\hline \multirow[b]{2}{*}{ Cultivar } & \multirow[b]{2}{*}{ Treatment } & \multicolumn{4}{|c|}{2013} & \multicolumn{4}{|c|}{2014} \\
\hline & & $\begin{array}{c}\text { Harvest } \\
\text { date }\end{array}$ & $\begin{array}{l}\text { Fruit size } \\
\quad(\mathrm{mm})\end{array}$ & $\begin{array}{c}\text { Titratable } \\
\text { acidity }\left(g \cdot \mathrm{L}^{-1}\right)\end{array}$ & $\begin{array}{c}\text { Soluble } \\
\text { solids (\%) }\end{array}$ & $\begin{array}{c}\text { Harvest } \\
\text { date }\end{array}$ & $\begin{array}{l}\text { Fruit size } \\
(\mathrm{mm})\end{array}$ & $\begin{array}{c}\text { Titratable } \\
\text { acidity }\left(\mathrm{g} \cdot \mathrm{L}^{-1}\right)\end{array}$ & $\begin{array}{c}\text { Soluble } \\
\text { solids (\%) }\end{array}$ \\
\hline \multirow[t]{2}{*}{ Sandra Rose } & Control & 12 July & 27.0 & 9.18 & 20.7 & 8 July & 29.9 & 9.81 & 22.5 \\
\hline & GA & 18 July & 30.4 & 8.39 & 21.1 & 11 July & 27.8 & 10.32 & 18.7 \\
\hline \multirow[t]{2}{*}{ Summit } & Control & 16 July & 29.0 & 6.94 & 20.3 & 11 July & 30.2 & 7.06 & 20.9 \\
\hline & GA & 23 July & 30.9 & 7.31 & 23.0 & 16 July & 30.7 & 8.57 & 19.4 \\
\hline \multirow[t]{2}{*}{ Lapins } & Control & 19 July & 29.7 & 6.24 & 17.6 & 14 July & 27.3 & 6.09 & 18.7 \\
\hline & GA & 26 July & 31.0 & 9.42 & 19.8 & 21 July & 30.3 & 9.40 & 18.5 \\
\hline \multirow[t]{2}{*}{ Skeena } & Control & 22 July & 29.9 & 9.08 & 21.5 & 17 July & 28.0 & 10.28 & 20.8 \\
\hline & GA & 25 July & 29.6 & 9.83 & 19.9 & 22 July & 29.0 & 8.59 & 21.3 \\
\hline \multirow[t]{2}{*}{ Sumtare } & Control & 31 July & 25.5 & 9.42 & 21.6 & 30 July & 27.3 & 7.72 & 20.5 \\
\hline & GA & 1 Aug. & 28.5 & 10.28 & 23.5 & 5 Aug. & 28.5 & 10.27 & 23.3 \\
\hline \multirow[t]{2}{*}{$13 \mathrm{~S} 2009$} & Control & 12 Aug. & 25.9 & 8.56 & 22.4 & 11 Aug. & 28.1 & 8.19 & 21.2 \\
\hline & GA & 9 Aug. $^{\mathrm{z}}$ & 29.2 & 10.32 & 21.2 & 18 Aug. & 30.0 & 8.87 & 21.1 \\
\hline
\end{tabular}

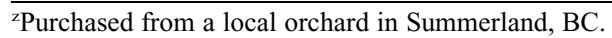

respectively, hereafter their cultivar names are used. Since ' 13 S2009' GA-treated fruit was unavailable from SuRDC in 2013, it was purchased from a local grower.

All fruit were harvested at commercial maturity early in the day $(\approx 7: 00-9: 00$ AM) to avoid firmness differences associated with diurnal variation (Mitcham, 2015). Fruit was harvested based on color and flavor as determined by at least two sensory personnel. Harvested fruit matched color chips no. 6 or no. 7 on the 7-category Center Technique Interprofessionnel des Fruits et Légumes (CTIFL) color chart (CTIFL, Paris, France). Cherries were sorted to remove any damaged fruit.

Firmness measurements on fresh and stored cherries. The firmness of 300 cherries was measured on the day of harvest (storage time $=0 \mathrm{~d}$ ) using the FirmTech2 Fruit Firmness Tester (Bioworks Inc., Wamego, $\mathrm{KS}$ ), in batches of 25 fruit. Fruit was loaded onto the instrument's turntable, containing 25 circular indentures, which rotated and positioned each cherry under a small load cell. This instrument applied a predetermined force $(1.96 \mathrm{~N})$ to the cheek of the cherry, compressing it by $1 \mathrm{~mm}$ and measuring the rate at which this force increased (Mitcham et al., 1998) in units of N.mm ${ }^{-1}$.

Firmness was measured twice; the first measurement was used to "set" the cherry in the indenture and the second measurement was recorded. A 60-fruit subsample (five fruit from each group of 25 cherries) was set aside for compositional analyses as described below. The occurrence of fruit (\%) in each of 32 firmness categories was determined. Categories were selected in 20 gravitational force $/ \mathrm{mm}\left(0.196 \mathrm{~N} \cdot \mathrm{mm}^{-1}\right)$ increments.

A further 300 fruit were packaged in four 2-lb clamshells of 75 cherries each. Packed clamshells were fitted with a paper liner to absorb moisture, and were precooled to $0.1{ }^{\circ} \mathrm{C}$ before storing in freshLOK Cherry Modified Atmosphere Packaging (MAP) bags (Shields Bag and Printing, Yakima, WA). Firmness was measured on cold fruit taken from the MAP bags after $7 \mathrm{~d}$ of storage (storage time $=7 \mathrm{~d}$ ), as indicated above. A 60 -fruit subsample was again set aside for compositional analyses. A 7-d storage period was selected to 1) approximate the length of time cherries would be in storage if air shipped to their destination, and 2) track the increase in firmness that occurs when cherries are stored (Wang et al., 2014).

Size and compositional analyses. Fruit size was quantified by evaluating the diameter of the cherries $(n=300)$ in millimeters. Evaluations were performed concurrently with firmness, with the FirmTech2 Fruit Firmness Tester. Titratable acidity (TA) and soluble solids concentration (SSC) were measured on juice extracted from each 60 -fruit subsample. Stems were removed, cherries were placed in a resealable bag, and juice was extracted by squeezing the cherries by hand. TA was determined by titrating a $10 \mathrm{~mL}$ juice sample with $0.1 \mathrm{~N} \mathrm{NaOH}$ using a Model 848 Titrino Plus Titrator (Metrohm, Herisau, Switzerland) and were reported as $\mathrm{g} \cdot \mathrm{L}^{-1}$ malic acid equivalents (Table 1). SSC was determined using a hand-held Refracto 30PX digital refractometer (Mettler Toledo, Columbus, $\mathrm{OH}$ ) and reported as percent (\%) (Table 1). TA and SSC were conducted once.

Characterization of frequency distributions. Frequency distributions were plotted for the 48 cherry samples with the percentage of fruit in each of the 32 firmness categories, using MS Excel (MS Office, Redmond, WA).

Descriptive statistics (mean, median, SD, minimum, maximum, range, skewness, excess kurtosis) were calculated using MS Excel. Since skewness and excess kurtosis values were determined on a sample, it was necessary to evaluate if they were present in the underlying population, using the test statistics $Z_{\mathrm{g} 1}$ and $\mathrm{Z}_{\mathrm{g} 2}$, respectively (Brown, 2015). If $Z_{\mathrm{g} 1}$ (or $Z_{\mathrm{g} 2}$ ) values are less than -2 or greater than +2 , they reflect a high likelihood of negative and positive skewness (or kurtosis) in the underlying population, respectively (Brown, 2015). Normality of the frequency distributions was assessed using the D'Agostino-Pearson (DP) omnibus test ( $\mathrm{DP}=\mathrm{Z}_{\mathrm{g} 1}{ }^{2}+\mathrm{Z}_{\mathrm{g} 2}{ }^{2}$ ). Exact probabilities were determined using an online calculator (Soper, 2015).

Exponential models, of the form $\mathrm{Y}=\mathrm{k} \mathrm{X}^{\mathrm{n}}$, were fitted to the firmness values where $Y$ was the percent occurrence, $\mathrm{X}$ was the midpoint of the firmness intervals, and $\mathrm{n}$ and $\mathrm{k}$ were the constant and exponent, respectively. The peak (maximum percent occurrence) was identified by inspection, and used to fit models for both the ascending and descending portions of the distributions. This resulted in the determination of four parameters: ascending-n (asc-n), descending-n (desc-n), ascending-k (asc-k), and descending-k (desc-k). The exponent (n) quantified the steepness and the direction $( \pm)$ of the slope, whereas the constant $(\mathrm{k})$ corresponded to the intercept. The coefficient of determination $\left(r^{2}\right)$ was used to ascertain the goodness of fit of the exponential models, for the ascending $\left(\right.$ asc- $\left.r^{2}\right)$ and descending (desc- $\left.r^{2}\right)$ portions of the distributions.

Distributions were also assessed for the proportion of fruit that was "too soft" (percentage $<2.56 \mathrm{~N} \cdot \mathrm{mm}^{-1}$ ) and "too hard" (percentage $>4.71 \mathrm{~N} \cdot \mathrm{mm}^{-1}$ ) (Hampson et al., 2014).

Scatter plots of the mean firmness and SD from the 48 cherry firmness distributions ( 6 cultivars $\times 2$ treatments $\times 2$ storage times $\times$ 2 years) were used to show the variation due to cultivar, treatment, storage times, and years. Descriptive statistics and curve fitting calculations were performed using MS Excel.

Analysis of variance and PCA. Analysis of variance (ANOVA) was conducted on 14 parameters obtained from the distributions (mean, median, SD, minimum, maximum, range, skewness, excess kurtosis, asc-n, desc-n, asc-k, desc-k, proportion of "too soft" fruit, and proportion of "too hard" fruit), using Statistical Analysis Systems (SAS) software (SAS Institute, Cary, NC). A three-factor ANOVA model [cultivar (c), treatment $(\mathrm{t})$, storage time (s)] with all two-factor interactions $(\mathrm{c} \times \mathrm{t}, \mathrm{c} \times \mathrm{s}, \mathrm{t} \times \mathrm{s})$ was performed by year (2013 and 2014), using the SAS general linear model procedure. Mean separations were also determined for main effects (cultivar, treatment, and storage time) using Fisher's least significant difference tests.

ANOVA served to identify three nonsignificant variables (excess kurtosis, asc-k, and desc-k), which could be dropped from subsequent multivariate statistical analysis. SAS normality tests confirmed normality of the parameters before ANOVA, with the 
exception of: the percentage of "too soft" and "too hard" fruit. For these two parameters, post hoc tests were interpreted with caution. Multivariate ANOVA (MANOVA) was performed to evaluate cultivar effects across all parameters.

Preliminary PCAs were performed by year and storage time, on the 11 significant parameters $(k=11)$ (mean, median, $\mathrm{SD}$, minimum, maximum, range, skewness, asc-n, desc-n, and proportion of "too soft" and "too hard" fruit). In these analyses, the number of samples $(\mathrm{n}=12)$ was greater than the number of attributes $(k=11)$ and underdetermination was avoided (Dettmar et al., 2015). The resultant biplots from these analyses were extremely similar (data not shown); therefore, a single PCA was performed on the entire data set (48 samples; 6 cultivars $\times 2$ treatments $\times 2$ storage times $\times 2$ years), allowing all the data to be interpreted together.

The resultant biplot from the analysis with 48 samples was extremely cluttered (data not shown), so two subplots were created (2013, $\mathrm{n}=24$ and 2014, $\mathrm{n}=24)$. Samples were identified by cultivar and ellipses drawn around the treatments, for each storage time to aid in visualizing the results and to facilitate interpretation of the data. Vector loadings for principal component (PC) 1, PC 2 , and PC 3 were tabulated. Analyses were performed using the factor procedure in SAS and the correlation matrix.

\section{Results and Discussion}

Scatter plots of means and correlation with compositional analyses. Scatter plots of mean firmness and SD values showed the variation among the cultivars (Fig. 1A), between the treatments (Fig. 1B), storage times (Fig. 1C), and years (Fig. 1D). The most striking feature of the plots was the lack of discernment of the effects, with the following exceptions: 1) the groupings of the 'Summit' and 'Sumtare' cherries were uniquely separated from each other (Fig. 1A), 2) a few very soft fresh cherry samples, with mean firmness values less than $1.96 \mathrm{~N} \cdot \mathrm{mm}^{-1}$ and low SD were different from a few very firm stored cherries, with mean firmness values greater than 3.63 $\mathrm{N} \cdot \mathrm{mm}^{-1}$ and larger sD (Fig. 1C), and 3) a few soft cherries in 2014, with firmness values between 1.58 and $1.96 \mathrm{~N} \cdot \mathrm{mm}^{-1}$, had lower SD than most of the cherries from either 2013 or 2014. The lack of discernment of the effects (Fig. 1A-D) suggested that a complex combination of factors was responsible for firmness of cherries. This is in contrast to the patterns observed for apples, where Zhang and Robson (2002) were able to correlate fruit weight and SD for five apple cultivars.

Characteristics of firmness distributions. Selected descriptive statistics of the firmness distributions for 2013 and 2014 are shown in Tables 2 and 3, respectively. The symmetry of the firmness distributions was given by the skewness value $\left(\mathrm{G}_{1}\right)$. The distributions were not skewed if the values were between +0.5 and -0.5 , moderately skewed if the values
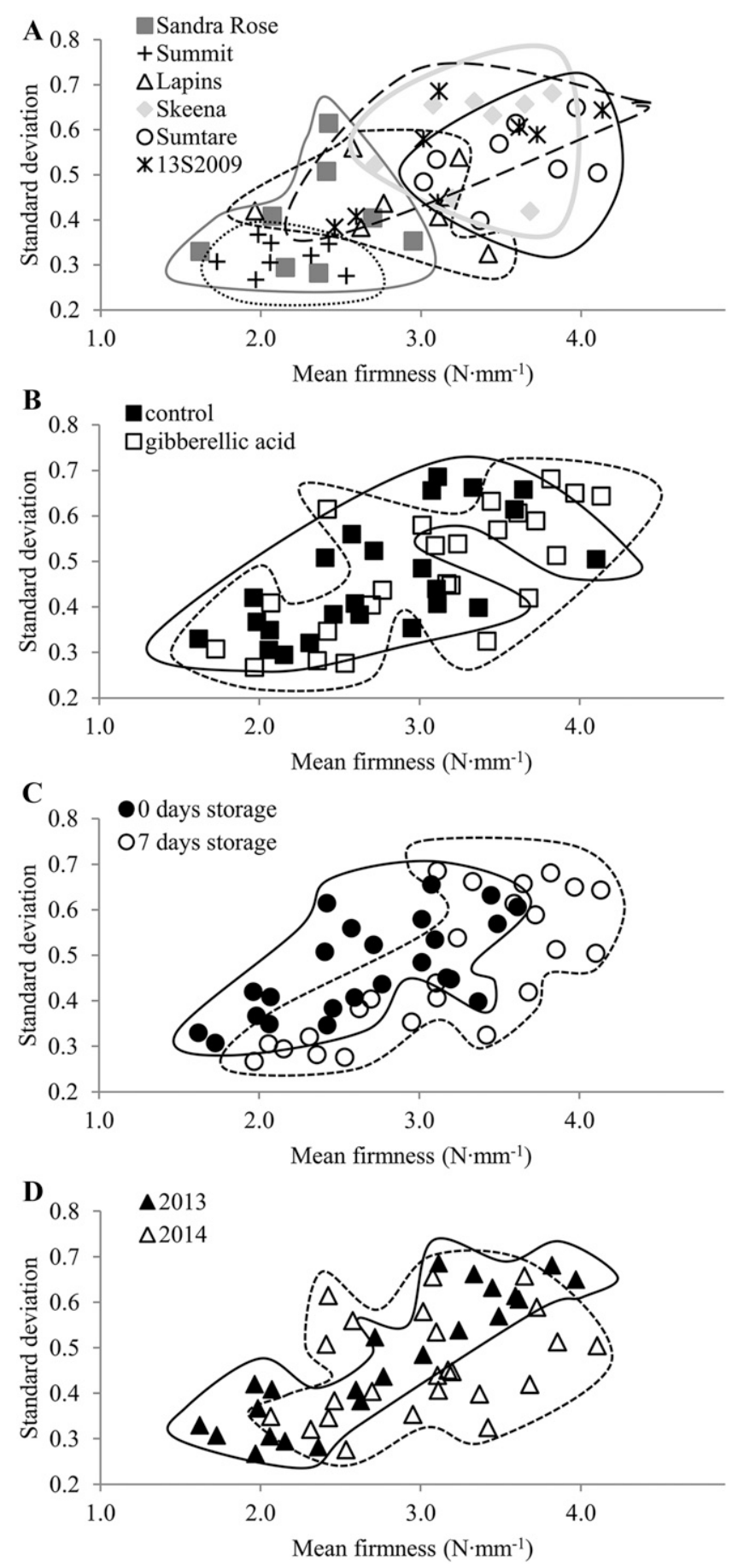

Fig. 1. Scatter plots of mean firmness and SD values for 48 cherry samples identified by: (A) cultivar (Sandra Rose, Summit, Lapins, Skeena, Sumtare, and 13S2009), (B) treatment (control and gibberellic acid), (C) storage time (0 and $7 \mathrm{~d}$ ), and (D) year (2013 and 2014). Cultivars, treatments, storage times, and years were encircled to aid in visualization.

were between -0.5 and -1 or +0.5 and +1 , and highly skewed if the values were less than -1 or greater than +1 (Bulmer, 1979). In 2013, three distributions were moderately or highly positively skewed (Table 2); whereas in 2014, six distributions were moderately or highly positively skewed (Table 3 ). These positively skewed values indicate that a greater proportion of firmness values were above rather than below the mean. In 2013, two distributions were moderately or highly negatively skewed (Table 2); whereas in 2014, five distributions were moderately or highly negatively skewed (Table 3 ). These negatively skewed values indicate that the distributions had a greater proportion of firmness values below rather than above the mean. Representative negatively and positively skewed distributions are shown in Fig. 2A and $\mathrm{B}$, respectively.

Interestingly, all moderately/highly positively skewed distributions were observed for 'Sandra Rose' in both 2013 and 2014 (Tables 2 and 3), with three exceptions (2013: 


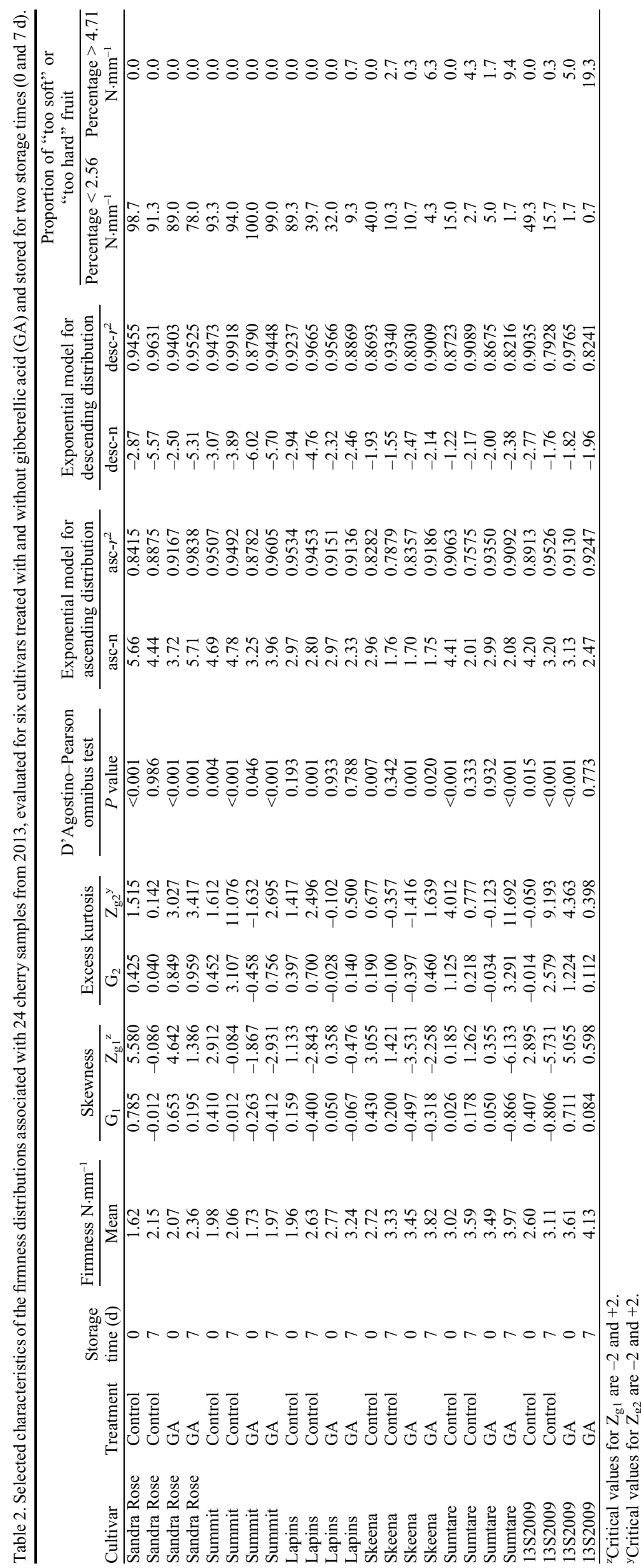

'13S2009' GA 0 d storage; 2014: 'Sumtare' GA $0 \mathrm{~d}$ storage and '13S2009' GA $0 \mathrm{~d}$ storage). The other moderately/highly skewed distributions were negative in 2013 ('Sumtare' GA 7 d storage and ' $13 \mathrm{~S} 2009$ ' control $7 \mathrm{~d}$ storage) (Table 2) and 2014 ('Summit' GA 0 d storage, 'Lapins' control 0 d storage, 'Lapins' GA 0 d storage, 'Skeena' control $0 \mathrm{~d}$ storage, and 'Sumtare' control $7 \mathrm{~d}$ storage) (Table 3). This suggested that the occurrence of skewness may be in part influenced by genotype and year. Although the positive skew might be considered advantageous, in this research the highly positively skewed distributions were associated with 'Sandra Rose' values (Table 4). This particular cultivar had a very low mean firmness value (2013: $2.05 \mathrm{~N} \cdot \mathrm{mm}^{-1}$; 2014: $2.62 \mathrm{~N} \cdot \mathrm{mm}^{-1}$ ), compared with '13S2009', 'Skeena', and 'Sumtare' with means of 3.36, 3.33 , and $3.52 \mathrm{~N} \cdot \mathrm{mm}^{-1}$ in 2013 and 3.08 , 3.40 , and $3.61 \mathrm{~N} \cdot \mathrm{mm}^{-1}$ in 2014 , respectively (Supplemental Table 1).

The test statistic $Z_{\mathrm{g} 1}$ assessed the likelihood of skewness in the entire population, not just a sample of cherries. A high fraction of values was less than -2 or greater than +2 , in $2013(12 / 24)$ (Table 2) and $2014(14 / 24)$ (Table 3 ) and were very likely from skewed populations.

The peakedness/flatness of the distributions was given by "excess" kurtosis. Although kurtosis for a normal distribution is 3 , the "excess" kurtosis value calculated by MS Excel has already been subtracted from 3 . Distributions with excess kurtosis values less than 0 are called platykurtic; these distributions have a central peak that is lower and broader, and tails that are shorter and thinner than a normal distribution (Brown, 2015; DeCarlo, 1997). Distributions with excess kurtosis values greater than zero are called leptokurtic; these distributions have a central peak that is higher and sharper, and tails that are longer and fatter than a normal distribution (Brown, 2015; DeCarlo, 1997). In this research, most distributions in 2013 (18/ 24) (Table 2) and in 2014 (19/24) (Table 3) were leptokurtic. Representative sample distributions with low and high excess kurtosis values are shown in Fig. $2 \mathrm{C}$ and D, respectively.

Since excess kurtosis values were determined from samples, the test statistic $Z_{\mathrm{g} 2}$ was used to assess the likelihood of excess kurtosis in the entire population of cherries. The $\mathrm{Z}_{\mathrm{g} 2}$ test statistics indicated that many underlying populations $(9 / 24)$ in 2013 (Table 2) and most populations (16/24) in 2014 (Table 3 ) very likely had positive excess kurtosis. A few samples had negative excess kurtosis (Tables 2 and 3), but none were of sufficient magnitude to reflect flat distributions in the population.

The DP omnibus test revealed that many of the distributions were nonnormal in $2013(16 / 24)$ (Table 2) and in 2014 (18/ 24) (Table 3 ). Standard parametric statistics require data to be normally distributed; therefore, ANOVA should be applied to firmness data with caution, or not at all. 


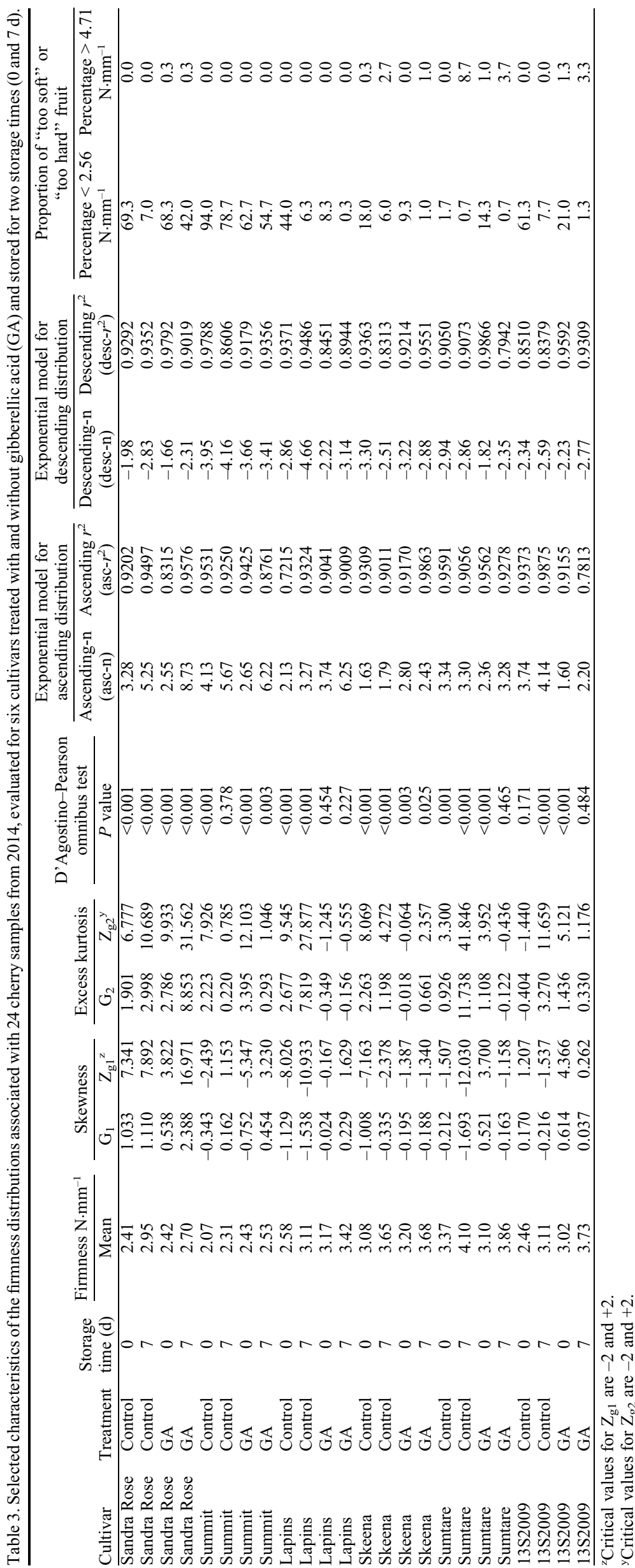

Although ANOVA can tolerate some deviations from normality (Glass et al., 1972; Lix et al., 1996), the usual approach for analysis of highly nonnormal data is to transform the values before analyses, or conduct nonparametric ANOVA. However, nonparametric ANOVA would not be appropriate for this research for it requires that the group (cultivar) distributions have the same "shape" (McDonald, 2014). As noted above, this was not the case; the distributions for 'Sandra Rose' were uniquely positively skewed.

Twelve of the 14 parameters calculated from the distributions were normally distributed (data not shown), with the exception of proportion of "too soft" and "too hard" fruit; ANOVA was performed on the mean, median, SD, minimum, maximum, and range (Supplemental Table 1) and skewness, asc-n, and desc-n (Table 4)

Exponential models and descriptive statistics for characterizing frequency distributions. The exponential model $\left(\mathrm{Y}=\mathrm{kX}^{\mathrm{n}}\right)$ provided a good fit for characterizing the ascending and descending portions of the curve peaks, as evident from the magnitude of the $r^{2}$ values (Tables 2 and 3). The $r^{2}$ values were particularly high given the relatively small numbers of data points used to calculate the regressions $(n=5-8)$.

The absolute value of the exponent (asc-n, desc-n) provided an index of the steepness of the peak, with the highest asc-n (representing a steep ascent) observed for 'Sandra Rose' (Table 4). These values were more than twice that of those observed for 'Skeena' (Table 4). The lowest desc-n (representing a steep descent) were observed for 'Sandra Rose' and 'Summit' in 2013, and 'Lapins' and 'Summit' in 2014 (Table 4); whereas the highest desc-n were observed for 'Skeena', 'Sumtare', and '13S2009' (Table 4).

The similarity of the asc-n and desc-n values for 'Sandra Rose' in 2013 was indicative of the symmetry of the peaks: they were considerably more peaked than a normal distribution. However, on average, 'Summit', 'Sumtare', and '13S2009' were the most peaked, with the highest kurtosis values in 2013 (Table 4).

The dissimilarity of the asc- $n$ and desc- $n$ values for 'Sandra Rose' in 2014 was indicative of very asymmetrical peaks, which were extremely peaked as well as highly positively skewed (Table 4). These new parameters (asc-n, desc-n) provided additional information (steepness and symmetry) regarding the distributions, which augmented conventional descriptive statistics.

Although 'Sandra Rose' distributions were on average positively skewed, the other cultivars were either nonskewed or negatively skewed (Table 4). On average, the distributions for 'Sumtare' were highly peaked with slight to moderate skewness (Table 4) in 2013 and 2014; whereas those for '13S2009' were highly peaked with none to slight skewness (Table 4). As such, fruit from 'Sumtare' and ' 13 S2009' would be the most "uniform" - a trait which would be advantageous to the industry. 

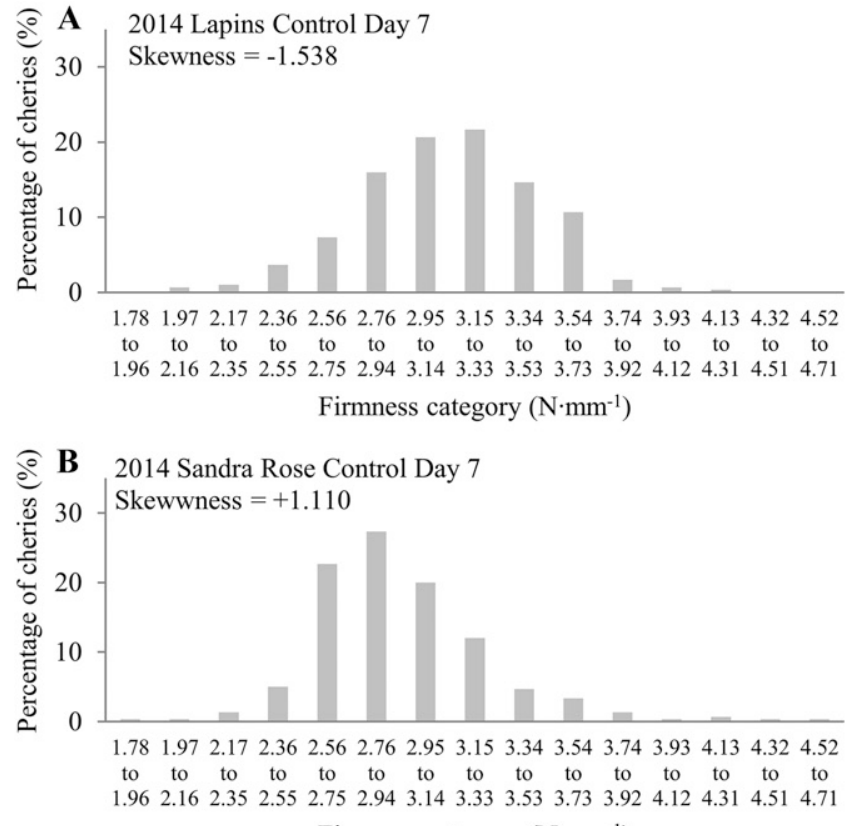

Firmness category $\left(\mathrm{N} \cdot \mathrm{mm}^{-1}\right)$

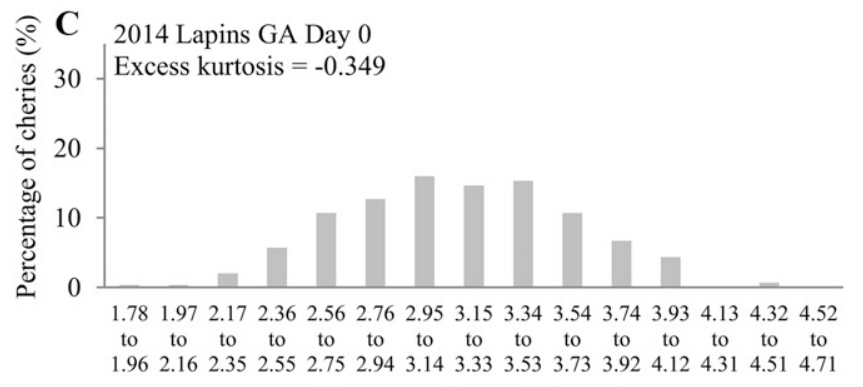

Firmness category $\left(\mathrm{N} \cdot \mathrm{mm}^{-1}\right)$

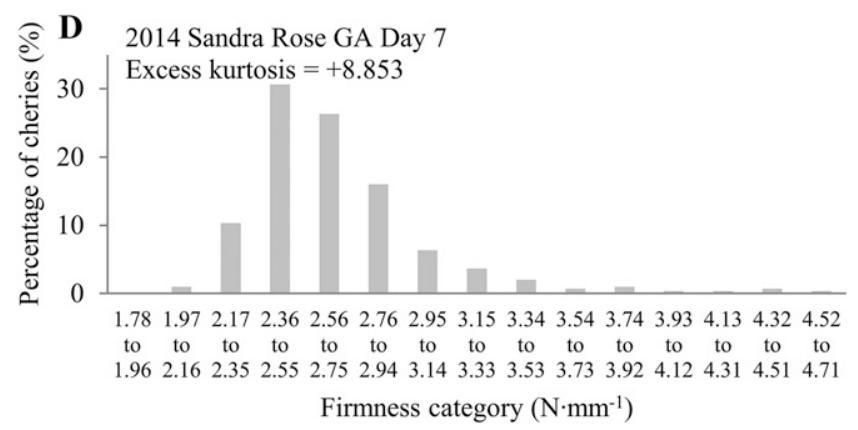

Fig. 2. Representative cherry firmness distributions showing the percentage of fruit in each of 32 firmness categories for cherry samples with (A) low skewness, (B) high skewness, (C) low excess kurtosis, and (D) high excess kurtosis values.

Area-under-the-curve statistics. Areaunder-the-curve statistics identified the proportion of "too soft" and "too hard" fruit (2013, Table 2; 2014, Table 3). On average, 'Sandra Rose' and 'Summit' had a high percentage of "too soft" fruit in both 2013 and 2014 (Table 4). 'Lapins' had intermediate percentages of "too soft" fruit, whereas the other cultivars (Skeena, Sumtare, and 13S2009) had lower percentages of "too soft" fruit, with the exception of ' 13 S2009' in 2014 with an intermediate percentage (Table 4). These trends are consistent with: the low mean (and median) firmness values associated with 'Sandra Rose' and 'Summit', intermediate values associated with 'Lapins', and high values associated with 'Skeena', 'Sumtare', and '13S2009' (Supplemental Table 1).

In contrast, the proportion of fruit that was "too hard" was extremely low for "Sandra Rose', 'Summit', and 'Lapins' in both 2013 and 2014; values were slightly higher for 'Skeena', 'Sumtare', and '13S2009' (Table 4). Although such fruit may be classified as "too hard" by consumers (Hampson et al., 2014), it would not likely result in the rejection of a commercial load and could be beneficial to the distributors/retailers for extended shelf life.
Cherries treated with GA had lower percentages of "too soft" fruit in 2013 and 2014 but higher percentages of "too hard" fruit in 2014 only (Table 4). Stored cherries had lower percentages of "too soft" fruit and higher percentages of "too hard" fruit in both years (Table 4). The magnitudes of these treatment effects due to GA and storage were considerable; however, statistical differences were not interpreted due to the nonnormality of the data.

ANOVA and MANOVA of distribution parameters. ANOVA served as a screening tool to identify significant variables for the PCA. As such a detailed interpretation of the mean separations (Supplemental Table 1; Table 4) was beyond the scope of this research and is available from the authors on request. Interestingly, the separation of the effects (cultivar, treatment, and storage time) was identical, for the mean and median parameters. This suggested that ANOVA can be applied to firmness parameters, although the underlying distributions were nonnormal. MANOVA confirmed the presence of cultivar effect $(2013, \lambda=0.00012, P=0.046$; 2014, $\lambda=0.00005, P=0.014)$, although multiple post hoc tests were conducted on the same data set and can sometimes result in erroneous type I errors.

Principal component analysis. PCA of the 11 significant firmness parameters (Fig. 3A and $\mathrm{B}$ ) accounted for $74.7 \%$ of the variation, with $56.5 \%$ and $18.2 \%$ explained by PC 1 and PC 2, respectively. An additional $10.5 \%$ was explained in the third dimension along PC 3 (Table 5). The most striking feature between the plots was the similarity in location of the cultivars in 2013 and 2014 (Fig. 3A and B). 'Summit' and 'Sandra Rose' were positioned further to the left (Fig. 3A and B), with the exception of 'Sandra Rose' samples that were more centrally located in 2014 (Fig. 3B). In both years, 'Lapins' were positioned centrally, whereas 'Skeena', 'Sumtare', and '13S2009' were positioned further to the right (Fig. 3A and B). The '13S2009' GA sample in 2013 (7 d) was located furthest to the right (Fig. 3A). This sample was particularly firm, in part because it had to be acquired elsewhere and the cherries were slightly less mature with lower SSC and higher TA (Table 1).

Separation along PC 1 , in the positive direction, was primarily attributed to differences in mean, median, SD, maximum, range, desc-n, and "too hard" fruit, as reflected by the high positive factor loadings (Table 5). Separation along PC 1 , in the negative direction, was primarily attributed to asc-n and "too soft" fruit, as reflected by the high negative factor loadings (Table 5). Thus, PC 1 differentiated the cultivars along a continuum from soft to firm, moving from left to right. 'Summit' and 'Sandra Rose' located furthest to the left along PC 1 had the lowest values for mean, median, SD, maximum, range, desc-n, and "too hard" fruit, and highest values for asc-n and "too soft" fruit, consistent with Supplemental Table 1 and Table 4. In contrast, 'Skeena' and 'Sumtare', 
Table 4. Means ${ }^{\mathrm{z}}$ of six parameters for characterizing the firmness frequency distributions of sweet cherry samples from $2013(\mathrm{n}=24)$ and $2014(\mathrm{n}=24)$.

\begin{tabular}{|c|c|c|c|c|c|c|c|}
\hline Main effects & $\mathrm{n}$ & Skewness & $\begin{array}{l}\text { Excess } \\
\text { Kurtosis }\end{array}$ & $\begin{array}{l}\text { Ascending-n } \\
\text { (asc-n) }\end{array}$ & $\begin{array}{l}\text { Descending-n } \\
\text { (desc-n) }\end{array}$ & $\begin{array}{l}\text { Proportion }{ }^{z} \text { of } \\
\text { "too soft"y } \\
\text { fruit }\end{array}$ & $\begin{array}{l}\text { Proportionz of } \\
\text { "too hard" } \\
\text { fruit }\end{array}$ \\
\hline \multicolumn{8}{|c|}{ (2) } \\
\hline \multicolumn{8}{|l|}{ Cultivar } \\
\hline Sandra Rose & 4 & $0.405 \mathrm{a}$ & $0.57 \mathrm{a}$ & $4.88 \mathrm{a}$ & $-4.06 \mathrm{c}$ & $89.3 \mathrm{a}$ & $0.0 \mathrm{a}$ \\
\hline Summit & 4 & $-0.069 \mathrm{a}$ & $0.96 \mathrm{a}$ & $4.17 \mathrm{ab}$ & $-4.67 \mathrm{c}$ & $96.6 \mathrm{a}$ & $0.0 \mathrm{a}$ \\
\hline Lapins & 4 & $-0.065 \mathrm{a}$ & $0.30 \mathrm{a}$ & $2.77 \mathrm{~cd}$ & $-3.12 b$ & $42.6 \mathrm{~b}$ & $0.2 \mathrm{a}$ \\
\hline Skeena & 4 & $-0.046 \mathrm{a}$ & $0.38 \mathrm{a}$ & $2.04 \mathrm{~d}$ & $-2.02 \mathrm{a}$ & $16.3 \mathrm{c}$ & $2.3 \mathrm{a}$ \\
\hline Sumtare & 4 & $-0.153 \mathrm{a}$ & $1.15 \mathrm{a}$ & $2.87 \mathrm{~cd}$ & $-1.94 \mathrm{a}$ & $6.1 \mathrm{c}$ & $3.9 \mathrm{a}$ \\
\hline $13 S 2009$ & 4 & $0.099 \mathrm{a}$ & $0.98 \mathrm{a}$ & $3.25 \mathrm{bc}$ & $-2.08 \mathrm{a}$ & $16.9 \mathrm{c}$ & $6.2 \mathrm{a}$ \\
\hline \multicolumn{8}{|l|}{ Treatment } \\
\hline Control & 12 & $0.114 \mathrm{a}$ & $0.76 \mathrm{a}$ & $3.66 \mathrm{a}$ & $-2.87 \mathrm{a}$ & $53.3 \mathrm{a}$ & $0.6 \mathrm{~b}$ \\
\hline GA & 12 & $-0.057 \mathrm{a}$ & $0.57 \mathrm{a}$ & $3.00 \mathrm{a}$ & $-3.09 \mathrm{a}$ & $36.0 \mathrm{~b}$ & $3.6 \mathrm{a}$ \\
\hline \multicolumn{8}{|l|}{ Storage Time } \\
\hline $0 \mathrm{~d}$ & 12 & $0.243 \mathrm{a}$ & $0.31 \mathrm{a}$ & $3.55 \mathrm{a}$ & $-2.66 \mathrm{a}$ & $52.0 \mathrm{a}$ & $0.6 \mathrm{~b}$ \\
\hline $7 \mathrm{~d}$ & 12 & $-0.186 \mathrm{~b}$ & $1.02 \mathrm{a}$ & $3.11 \mathrm{a}$ & $-3.30 \mathrm{~b}$ & $37.2 \mathrm{~b}$ & $3.6 \mathrm{a}$ \\
\hline \multicolumn{8}{|l|}{2014} \\
\hline \multicolumn{8}{|l|}{ Cultivar } \\
\hline Sandra Rose & 4 & $1.267 \mathrm{a}$ & $4.14 \mathrm{a}$ & $4.95 \mathrm{a}$ & $-2.20 \mathrm{a}$ & $46.7 \mathrm{~b}$ & $0.2 \mathrm{a}$ \\
\hline Summit & 4 & $-0.120 b$ & $1.53 \mathrm{a}$ & $4.67 \mathrm{a}$ & $-3.79 \mathrm{~d}$ & $72.5 \mathrm{a}$ & $0.0 \mathrm{a}$ \\
\hline Lapins & 4 & $-0.616 \mathrm{~b}$ & $2.50 \mathrm{a}$ & $3.85 \mathrm{ab}$ & $-3.22 \mathrm{c}$ & $14.7 \mathrm{~cd}$ & $0.0 \mathrm{a}$ \\
\hline Skeena & 4 & $-0.432 \mathrm{~b}$ & $1.03 \mathrm{a}$ & $2.16 \mathrm{c}$ & $-2.98 b c$ & $8.6 \mathrm{~cd}$ & $1.0 \mathrm{a}$ \\
\hline Sumtare & 4 & $-0.387 \mathrm{~b}$ & $3.41 \mathrm{a}$ & $3.07 \mathrm{bc}$ & $-2.49 \mathrm{ab}$ & $4.4 \mathrm{~d}$ & $3.4 \mathrm{a}$ \\
\hline $13 \mathrm{~S} 2009$ & 4 & $0.151 \mathrm{~b}$ & $1.16 \mathrm{a}$ & $2.92 \mathrm{bc}$ & $-2.48 \mathrm{ab}$ & $22.8 \mathrm{c}$ & $1.2 \mathrm{a}$ \\
\hline \multicolumn{8}{|l|}{ Treatment } \\
\hline Control & 12 & $-0.333 \mathrm{~b}$ & $3.07 \mathrm{a}$ & $3.47 \mathrm{a}$ & $-3.08 \mathrm{~b}$ & $32.9 \mathrm{a}$ & $1.0 \mathrm{a}$ \\
\hline GA & 12 & $0.288 \mathrm{a}$ & $1.52 \mathrm{a}$ & $3.73 \mathrm{a}$ & $-2.64 \mathrm{a}$ & $23.7 \mathrm{a}$ & $0.9 \mathrm{a}$ \\
\hline \multicolumn{8}{|l|}{ Storage time } \\
\hline $0 \mathrm{~d}$ & 12 & $-0.066 \mathrm{a}$ & $1.50 \mathrm{a}$ & $2.83 \mathrm{~b}$ & $-2.68 \mathrm{a}$ & $39.4 \mathrm{a}$ & $0.2 \mathrm{a}$ \\
\hline $7 \mathrm{~d}$ & 12 & $0.021 \mathrm{a}$ & $3.09 \mathrm{a}$ & $4.38 \mathrm{a}$ & $-3.04 \mathrm{~b}$ & $17.2 \mathrm{~b}$ & $1.6 \mathrm{a}$ \\
\hline
\end{tabular}

${ }^{\mathrm{z}}$ Means for this parameter should be interpreted with caution due to nonnormality.

${ }^{y}$ Defined as the percentage of fruit with firmness values less than $2.56 \mathrm{~N} \cdot \mathrm{mm}^{-1}$.

${ }^{\mathrm{x}}$ Defined as the percentage of fruit with firmness values greater than $4.71 \mathrm{~N} \cdot \mathrm{mm}^{-1}$.

located further to the right along PC 1 had the highest values for mean, median, SD, maximum, range, desc-n, and "too hard" fruit, and lowest values for "too soft" fruit, consistent with Supplemental Table 1 and Table 3. The centrally located 'Lapins' had intermediate values for these characteristics.

Separation along PC 2 was primarily attributed to differences in minimum and skewness values, as reflected by their high + factor loadings (Table 5). Separation along PC 3 in the third dimension (data not shown) explained an additional $10.5 \%$ of the variation (Table 5) and was primarily attributed to desc-n and to a lesser extent skewness (Table 5).

Cultivar differences (Fig. 3A and B) could be attributed to differences in the ability to regulate internal electrolyte concentrations (Bolarin et al., 1993), the thickness of the hemicellulose chains (Chen et al., 2009), the type and concentration of constituents in the cell walls (Choi et al., 2002a; Salato et al., 2013), as well as the cuticle composition (waxes and cutin) of the fruit epidermis both at harvest (Lara et al., 2015; Peschel et al., 2007) and after storage (Belge et al., 2014). Given that the mechanism(s) of action are related to structural components, one might expect smaller fruit to have a higher structural integrity. Indeed the smallest cultivar, Sumtare with the smallest diameter, relative to the other cultivars (Table 1), had the highest mean firmness $\left(2013,3.52 \mathrm{~N} \cdot \mathrm{mm}^{-1}\right.$; 2014, $3.61 \mathrm{~N} \cdot \mathrm{mm}^{-1}$ ) (Supplemental Table 1; Fig. $3 \mathrm{~A}$ and $\mathrm{B}$ ). Rootstocks have been shown to influence crop load (Hrotkó,
2008; Webster and Schmidt, 1996; Whiting et al., 2005), but not necessarily have a direct effect on size and firmness (Brown and Bourne, 1988). Campoy et al. (2015) have reported a significant negative correlation between fruit firmness and weight, a proxy of fruit size, in two F1 sweet cherry progenies.

GA differences were also apparent in Fig. 3A and B. In 2013, the position of the GA-treated sample was to the right of the control (C), with the exception of 'Summit' (Fig. 3A). This can be visualized by the "length" of the ellipses in the horizontal direction. This change in location in the plot was associated with increases in the mean firmness value and was consistent with the ANOVA (Supplemental Table 1), with mean values for the control and GA fruit (2013) of 2.56 and $3.05 \mathrm{~N} \cdot \mathrm{mm}^{-1}$, respectively (Supplemental Table 1). Such changes were consistent with values reported in the literature (Cline and Trought, 2007; Kappel and MacDonald, 2002), where some cultivars have a larger GA response than others (Kappel et al., 2002), particularly compared with the early-maturing cultivars (Choi et al., 2002b). Unfortunately, the GA response for ' 13 S2009' in 2013 could not be interpreted (Fig. 3A), for fruit had to be acquired elsewhere. However, the GA response for '13S2009' in 2014 (Fig. 3B) was particular large $\left(0 \mathrm{~d}, \Delta+0.56 \mathrm{~N} \cdot \mathrm{mm}^{-1}\right.$; $7 \mathrm{~d}, \Delta+0.62 \mathrm{~N} \cdot \mathrm{mm}^{-1}$ ) (Table 3) as evident from the "length" of the ellipse in Fig. 3B.

In 2014, the positions of two of the GAtreated samples were to the right of the control ('13S2009' and 'Summit') (Fig. 3B), as described above for 2013; however, the positions of other GA-treated samples ('Sandra Rose', 'Lapins', 'Skeena', and 'Sumtare') relative to their controls were located higher in the plane (Fig. 3B). This can be visualized by the "length" of the ellipse in the vertical direction. This change in location in the plot was associated with an increase in the minimum and skewness values, and was consistent with the ANOVA (Supplemental Table 1). On average, the minimum values for the control and GA fruit were 0.90 and $1.72 \mathrm{~N} \cdot \mathrm{mm}^{-1}$, respectively (Supplemental Table 1), whereas skewness values were -0.333 and 0.288 , respectively (Table 4). As such, this represented a change in shape of the distribution, where the average increase in the minimum was $\Delta+0.82 \mathrm{~N} \cdot \mathrm{mm}^{-1}$. Smaller increases were observed in $2013\left(\Delta+0.44 \mathrm{~N} \cdot \mathrm{mm}^{-1}\right)$, which were nonsignificant (Supplemental Table 1).

The PCA plots also revealed the relative magnitude of the storage effects. In general, the stored fruits $(7 \mathrm{~d})$ were located slightly higher and to the right of the fresh fruit $(0 \mathrm{~d})$, signifying fruit that were firmer and had higher minimum values. On average, stored fruit had higher firmness values than the fresh fruit $\left(2013, \Delta+0.44 \mathrm{~N} \cdot \mathrm{mm}^{-1} ; 2014, \Delta+0.48\right.$ $\mathrm{N} \cdot \mathrm{mm}^{-1}$ ) and higher minimum values (2014, $\left.\Delta+0.40 \mathrm{~N} \cdot \mathrm{mm}^{-1}\right)$ (Supplemental Table 1).

Finally, average fruit firmness in 2013 $\left(\overline{\mathrm{x}}_{\text {firmness }}=2.81 \mathrm{~N} \cdot \mathrm{mm}^{-1}\right)$ was lower than in $2014\left(\overline{\mathrm{x}}_{\text {firmness }}=3.02 \mathrm{~N} \cdot \mathrm{mm}^{-1}\right)(\mathrm{n}=48)$ (Supplemental Table 1), but not all cultivars responded similarly. The "soft" earlyharvest cultivars Summit and Sandra Rose had larger differences in firmness values between 2013 and 2014 ('Summit', $\Delta+0.40$ $\mathrm{N} \cdot \mathrm{mm}^{-1}$; 'Sandra Rose', $\Delta+0.57 \mathrm{~N} \cdot \mathrm{mm}^{-1}$ ) (Supplemental Table 1), whereas the firmer cultivars Skeena, Sumtare, and 13S2009 had smaller differences in firmness between 2013 and 2014 (Skeena, $\Delta+0.07 \mathrm{~N} \cdot \mathrm{mm}^{-1}$; Sumtare, $\Delta+0.09 \mathrm{~N} \cdot \mathrm{mm}^{-1} ; 13 \mathrm{~S} 2009, \Delta-0.28$ $\mathrm{N} \cdot \mathrm{mm}^{-1}$ ) (Supplemental Table 1). This suggested that firmness values were dependent on cultivar, harvest date, GA, and storage time. Firmness may also have been affected by the occurrence of precipitation close to each cultivar's harvest time, which varied considerably between the 2 years particularly for May and June (Supplemental Table 2). As such, this precipitation might have exerted a greater effect on the firmness of the earlyharvest cultivars. Alternatively, the cultivars may vary in their capacity for turgor maintenance (Ranney et al., 1991). It is believed that tree age, canopy shading, pruning, and crop load also contribute to the differences in firmness. While Proebsting and Mills (1981) did not observe a relationship between firmness and crop load for 'Bing' cherries, Facteau et al. (1983) were successful in developing regression models to predict firmness from the SSC and the natural logarithm of the leaf:fruit ratio. However, due to the large variability of the data, regression models had to be fitted to each of the orchards and years. 
A

Sandra Rose 2013

Summit 2013

A Lapins 2013

- Skeena 2013

- Sumtare 2013

४13S2009 2013

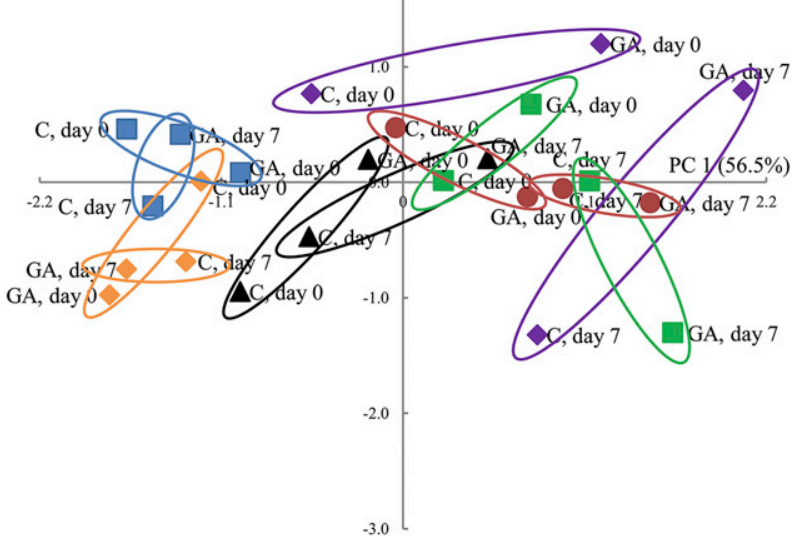

B

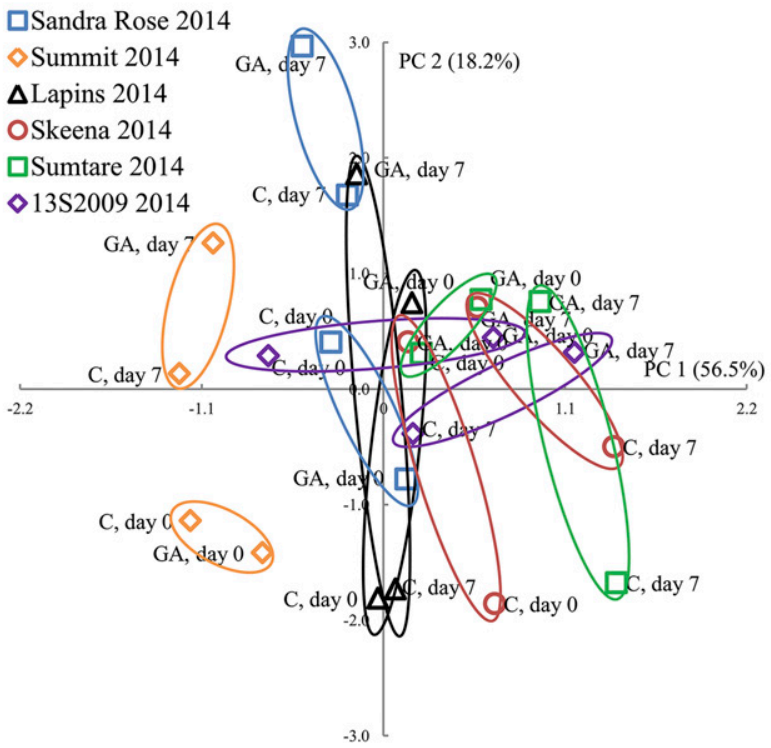

Fig. 3. Principal component analyses of 11 cherry firmness parameters for 48 cherry samples. For ease of visualization, sample coordinates were plotted on separate biplots for (A) 2013 and (B) 2014. Ellipses were drawn around cultivars (Sandra Rose, Summit, Lapins, Sumtare, Skeena, and 13S2009) for a given storage time ( 0 and $7 \mathrm{~d})$. Samples labeled with the experimental treatment [control (C) and gibberellic acid (GA)] and storage time $(0$ and $7 \mathrm{~d})$.

Table 5. Explained variance and factor loadings from principal component (PC) analyses of the 11 parameters from the 48 cherry firmness distributions.

\begin{tabular}{lccr}
\hline & PC 1 & PC 2 & PC 3 \\
\hline Variance & & & 10.5 \\
$\quad$ Explained variance (\%) & 56.5 & 18.2 & 85.2 \\
$\quad$ Cumulative explained variance (\%) & 56.5 & 74.7 & -0.285 \\
Factor loadings & & & -0.306 \\
Mean & $0.940^{\mathrm{z}}$ & 0.126 & 0.355 \\
Median & $0.937^{\mathrm{z}}$ & 0.091 & -0.312 \\
Standard deviation & $0.871^{\mathrm{z}}$ & -0.175 & 0.095 \\
Minimum & 0.237 & $0.863^{\mathrm{z}}$ & 0.300 \\
Maximum & $0.948^{\mathrm{z}}$ & 0.206 & 0.465 \\
Range & $0.825^{\mathrm{z}}$ & -0.347 & -0.051 \\
Skewness & -0.248 & $0.815^{\mathrm{z}}$ & 0.591 \\
Ascending-n & $-0.601^{\mathrm{z}}$ & 0.510 & 0.234 \\
Descending-n & $0.653^{\mathrm{z}}$ & 0.285 & -0.173 \\
Proportion of "too soft"y fruit & $-0.884^{\mathrm{z}}$ & -0.185 & \\
Proportion of "too hard" & $0.654^{\mathrm{z}}$ & -0.008 & \\
\hline
\end{tabular}

${ }^{\mathrm{z}}$ Values greater than 0.60 are considered heavily loaded $(-$ or +$)$.

${ }^{\mathrm{y}}$ Defined as the percentage of fruit with firmness values less than $2.56 \mathrm{~N} \cdot \mathrm{mm}^{-1}$.

${ }^{x}$ Defined as the percentage of fruit with firmness values greater than $4.71 \mathrm{~N} \cdot \mathrm{mm}^{-1}$.

\section{Conclusions}

This research demonstrated that a very high proportion of cherry firmness distributions were nonnormal. This suggested that the firmness values should not be analyzed using standard parametric statistics. However, selected descriptive parameters (mean, median, SD, minimum, maximum, range, and skewness) and peak characteristics (asc-n, desc-n) taken from the curves were normally distributed, and significant in evaluating cultivar, treatment, and seasonal effects. The work revealed that the firmness distributions for 'Sandra Rose' were primarily skewed to the right, whereas those from the other cultivars were primarily skewed to the left. The highly peaked distributions of 'Sumtare' and ' 13 S2009', with only modest negative skew, were the most uniform fruit. PCA could distinguish the three subgroups of cherries ["soft" ('Sandra Rose' and 'Summit'), "intermediate" ('Lapins'), and "firm" ('Skeena', 'Sumtare', and '13S2009')], whereas simple plots (mean firmness vs. SD) could not. Although seasonal variation was evident, GA and storage treatments increased the mean and minimum firmness and reduced the percentage of "too soft" fruit, with few exceptions. The late-harvest cultivar (13S2009) was softer than expected at harvest, but showed the greatest improvement in firmness with GA. The research provided insight into the nature of the firmness distributions for sweet cherries, which have important implications for industry, as well as used new/ alternate curve parameters for characterizing experimental effects.

\section{Literature Cited}

Belge, B., M. Llovera, E. Comabella, F. Gatius, P. Guilleìn, J. Graell, and I. Lara. 2014. Characterization of cuticle composition after cold storage of "Celeste" and "Somerset" sweet cherry fruit. J. Agr. Food Chem. 62:8722-8729.

Bolarin, M.C., F. Pérez-Alfocea, E.A. Cano, M.T. Estañ, and M. Caro. 1993. Growth, fruit yield and ion concentration in tomato genotypes after pre- and post-emergence salt treatments. J. Amer. Soc. Hort. Sci. 118:655-660.

Brown, S. 2015. Measures of shape: Skewness and kurtosis. 28 June 2015. <http://brownmath.com/ stat $/$ shape.htm $>$.

Brown, S.K. and M.C. Bourne. 1988. Assessment of components of fruit firmness in selected sweet cherry genotypes. HortScience 23:902-904.

Bulmer, M.G. 1979. Principles of statistics. Dover, New York, NY.

Campoy, J.A., L. Le Dantec, T. Barreneche, E. Dirlewanger, and J. Quero-García. 2015. New insights into fruit firmness and weight control in sweet cherry. Plant Mol. Biol. Rep. 33:783-796.

Chen, F., L. Zhang, H. An, H. Yang, X. Sun, H. Liu, Y. Yao, and L. Li. 2009. The nanostructure of hemicellulose of crisp and soft Chinese cherry (Prunus pseudocerasus L.) cultivars at different stages of ripeness. LWT-Food Sci. Technol. 42:125-130.

Choi, C., P. Toivonen, P.A. Wiersma, and F. Kappel. 2002a. Differences in levels of pectic substances and firmness in fruit from six sweet cherry genotypes. J. Amer. Pomol. Soc. $56: 197-201$. 
Choi, C., P.A. Wiersma, P. Toivonen, and F. Kappel. 2002b. Fruit growth, firmness and cell wall hydrolytic enzyme activity during development of sweet cherry fruit treated with gibberellic acid $\left(\mathrm{GA}_{3}\right)$. J. Hort. Sci. Biotechnol. 77:615-621.

Clarke, G.M. 1990. The relation between weight and diameter in apples. J. Hort. Sci. 65:385-393.

Cline, J.A. and M. Trought. 2007. Effect of gibberellic acid on fruit cracking and quality of Bing and Sam sweet cherries. Can. J. Plant Sci. 87:545-550.

DeCarlo, L.T. 1997. On the meaning and use of kurtosis. Psychol. Methods 2:292-307.

De Belie, N., I.C. Hallett, F.R. Harker, and J. De Baerdemaeker. 2000. Influence of ripening and turgor on the tensile properties of pears: A microscopy study of cellular and tissue changes. J. Amer. Soc. Hort. Sci. 125:350-356.

Dettmar, B., M. Plattner, and C. Vetter. 2015. Underdetermination in multivariate data analysis. 11th Pangborn Sensory Science Symposium, Poster Presentation P2.121. 23-27 Aug. 2015, Gothenburg, Sweden.

Dever, M.C., R.A. Macdonald, M.A. Cliff, and W.D. Lane. 1996. Sensory evaluation of sweet cherry cultivars. HortScience 31:150-153.

Drake, S.R., M.W. Williams, and J.B. Fountain. 1989. Stemless sweet cherry (Prunus avium L.) - fruit quality and consumer purchase. J. Food Qual. 11:411-416.

Facteau, T.J., N.E. Chestnut, and K.E. Rowe. 1983. Relationship between fruit weight, firmness, and leaf/fruit ratio in Lambert and Bing sweet cherries. Can. J. Plant Sci. 63:763-765.

Glass, G.V., P.D. Peckham, and J.R. Sanders. 1972. Consequences of failure to meet assumptions underlying the fixed effects analyses of variance and covariance. Rev. Educ. Res. 42:237288.

Government of Canada. 2015. Historical climate data. 8 Sept. 2015.<http://climate.weather.gc.ca/ climateData/dailydata_e.html?timeframe $=2 \&$ Prov $=\mathrm{BC} \% 20 \% 20 \&$ StationID $=979 \&$ dlyRange $=$ 1990-06-01|2015-07-02\&Year=2013\&Month= $5 \&$ Day $=2>$.

Hampson, C.R. 2014. Sweet cherry breeding in Summerland, Canada. Compact Fruit Tree 47 (2):13-14.

Hampson, C.R., K. Stanich, D.-L. McKenzie, L. Herbert, R. Lu, J. Li, and M.A. Cliff. 2014. Determining the optimum firmness for sweet cherries using Just-About-Right sensory methodology. Postharvest Biol. Technol. 91:104 111.

Harker, F.R., E.M. Kupferman, A.B. Marin, F.A. Gunson, and C.M. Triggs. 2008. Eating quality standards for apples based on consumer preferences. Postharvest Biol. Technol. 50:70-78.

Harker, F.R., M.G.H. Stec, I.C. Hallett, and C.L. Bennett. 1997. Texture of parenchymatous plant tissue: A comparison between tensile and other instrumental and sensory measurements of tissue strength and juiciness. Postharvest Biol. Technol. 11:63-72.

Hrotkó, K. 2008. Progress in cherry rootstock research. Acta Hort. 795:171-178.

Judd, M.J., K.J. McAneney, and K.S. Wilson. 1989. Influence of water stress on kiwifruit growth. Irr. Sci. 10:303-311.

Kappel, F. and R.A. MacDonald. 2002. Gibberellic acid increases fruit firmness, fruit size, and delays maturity of 'Sweetheart' sweet cherry. J. Amer. Pomol. Soc. 56:219-222.

Kappel, F., P. Toivonen, D.-L. McKenzie, and S. Stan. 2002. Storage characteristics of new sweet cherry cultivars. HortScience 37:139-143.

Landahl, S., W.B. Herppich, B. Herold, M. Geyer, and J. De Baerdemaeker. 2004. A comprehensive evaluation of the interactions between produce elasticity and water status. Eur. J. Hort. Sci. 69:S250-S257.

Lara, I., B. Belge, and L.F. Goulao. 2015. A focus on the biosynthesis and composition of cuticle in fruits. J. Agr. Food Chem. 63:4005-4019.

Lechaudel, M., G. Vercambre, F. Lescourret, F. Normand, and M. Génard. 2007. An analysis of elastic and plastic fruit growth of mango in response to various assimilate supplies. Tree Physiol. 27:219-230.

Lin, T.-T. and R.E. Pitt. 1986. Rheology of apple and potato tissue as affected by cell turgor pressure. J. Texture Stud. 17:291-313.

Lix, L.M., J.C. Keselman, and H.J. Keselman. 1996. Consequences of assumption violations revisited: A quantitative review of alternatives to the one-way analysis of variance $F$ test. Rev. Educ. Res. 66:579-619.

McDonald, J.H. 2014. Handbook of biological statistics, p. 133-136. 3rd ed. Sparky House Publishing, Baltimore, MD. 8 Sept. 2015. <http:// www.biostathandbook.com/normality.html $>$.

Mitcham, B. 2015. Stone fruit: Postharvest handling systems. Postharvest technology of horticultural crops short course. Postharvest Technology Center, UC Regents, Davis, CA. 25 July 2015. <http://www.ucanr.edu/datastoreFiles/ 234-2886.pdf $>$.

Mitcham, E.J., M. Clayton, and W.V. Biasi. 1998. Comparison of devices for measuring cherry fruit firmness. HortScience 33:723-727.

Péneau, S., P.B. Brockhoff, E. Hoehn, F. Escher, and J. Nuessli. 2007. Relating consumer evaluation of apple freshness to sensory and physico-chemical measurements. J. Sens. Stud. 22:313-335.

Peschel, S., R. Franke, L. Schreiber, and M. Knoche. 2007. Composition of the cuticle of developing sweet cherry fruit. Phytochemistry 68:1017-1025.

Proebsting, E.L. and H.H. Mills. 1981. Effects of season and crop load on maturity characteristics of 'Bing' cherry. J. Amer. Soc. Hort. Sci. 106:144-146.

Ranney, T.G., N.L. Bassuk, and T.H. Whitlow. 1991. Osmotic adjustment and solute constituents in leaves and roots of water-stressed cherry (Prunus) trees. J. Amer. Soc. Hort. Sci. 116:684-688.

Salato, G.S., N.M.A. Ponce, M.D. Raffo, A.R. Vicente, and C.A. Stortz. 2013. Developmental changes in cell wall polysaccharides from sweet cherry (Prunus avium L.) cultivars with contrasting firmness. Postharvest Biol. Technol. 84:66-73.

Searle, B., R. Renquist, and B. Bycroft. 2003. Agronomic factors affecting the variability of squash fruit weight. Agronomy N.Z. 32:27-34.

Soper, D. 2015. P-value calculator for a chi-square test. 1 July 2015. <http://www.danielsoper.com/ statcalc3/calc.aspx?id=11>.

Tijskens, L.M.M., P. Eccher Zerbini, R.E. Schouten, M. Vanoli, S. Jacob, M. Grassi, R. Cubeddu, L. Spinelli, and A. Torricelli. 2007. Assessing harvest maturity of nectarines. Postharvest Biol. Technol. 45:204-213.

United States Department of Agriculture (USDA). 2005. Sweet cherries shipping point and market inspection instructions. USDA Agricultural Marketing Service. Fresh Products Branch. p. 31. 10 Nov. 2015. <www.ams.usda.gov/AMSv1.0/ getfile?dDocName=STELPRDC5098253>.

Wang, Y., X. Xie, and L.E. Long. 2014. The effect of postharvest calcium application in hydrocooling water on tissue calcium content, biochemical changes, and quality attributes of sweet cherry fruit. Food Chem. 160:22-30.

Webb, R.A., J.V. Purves, and M.G. Beech. 1980. Size factors in apple fruit. Sci. Hort. 13:205-212.

Webster, A.D. and H. Schmidt. 1996. Rootstocks for sweet and sour cherries, p. 127-163. In: A.D. Webster and N.E. Looney (eds.). Cherries: Crop physiology, production and uses. CAB International, Wallingford, UK.

Whiting, M.D., G. Lang, and D. Ophardt. 2005. Rootstock and training system affect sweet cherry growth, yield, and fruit quality. HortScience 40:582-586.

Zhang, J. and A. Robson. 2002. Fitting normal distributions to apple fruit and its application. Acta Hort. 584:169-175. 
Supplemental Table 1. Means $\mathrm{z}^{\mathrm{z}}$ of six parameters for characterizing the firmness distributions of sweet cherry samples from $2013(\mathrm{n}=24)$ and 2014 $(\mathrm{n}=24)$.

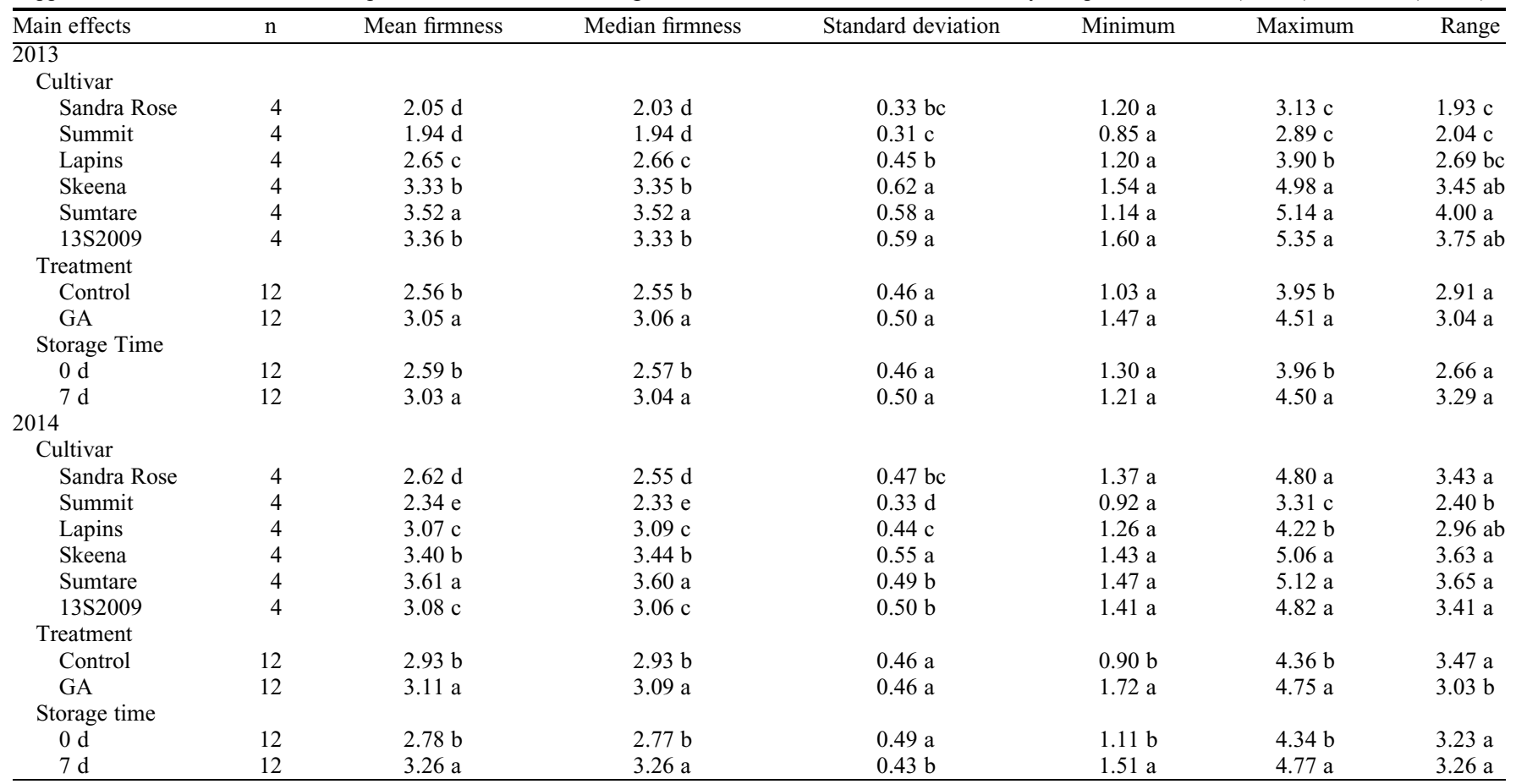

${ }^{\mathrm{z}}$ Mean separation of the main effects (cultivar, treatment, and storage time) using Fisher's least significant difference test, $P \leq 0.05$.

Supplemental Table 2. Climatic conditions (mean temperature and precipitation) over the growing season for the 2 years. ${ }^{\mathrm{Z}}$

\begin{tabular}{lrrrrr}
\hline & \multicolumn{2}{c}{ Mean temp $\left({ }^{\circ} \mathrm{C}\right)$} & & \multicolumn{2}{c}{ Precipitation $(\mathrm{mm})$} \\
\cline { 2 - 3 } \cline { 5 - 6 } Month & 2013 & 2014 & & 2013 & 2014 \\
\hline April & 8.9 & 8.8 & & 34.8 & 27.2 \\
May & 14.9 & 14.2 & & 55.2 & 34.4 \\
June & 17.8 & 17.4 & & 89.0 & 60.2 \\
July & 23.1 & 23.3 & & NA & 29.0 \\
August & 22.1 & 22.1 & & 23.4 & 13.6 \\
\hline
\end{tabular}

${ }^{\mathrm{z}}$ Government of Canada, 2015.

$\mathrm{NA}=$ Not available. 